\title{
Strandings of northern bottlenose whales, Hyperoodon ampullatus, in the north-east Atlantic: seasonality and diet
}

\author{
RUTH FERNÁNDEZ ${ }^{1,2}$, GRAHAM J. PIERCE ${ }^{1,3}$, COLIN D. MACLEOD ${ }^{1}$, ANDREW BROWNLOW ${ }^{4}$,
} ROBERT J. REID ${ }^{4}$, EMER ROGAN ${ }^{5}$, MARIAN ADDINK ${ }^{6}$, ROBERT DEAVILLE ${ }^{7}$, PAUL D. JEPSON ${ }^{7}$ AND M. BEGOÑA SANTOS 8

${ }^{1}$ School of Biological Sciences, University of Aberdeen, Tillydrone Avenue, Aberdeen, AB24 2TZ, UK, ${ }^{2}$ Centre for GeoGenetics, University of Copenhagen, Øster Volgade 5-7, 1350, Copenhagen, Denmark, ${ }^{3}$ CESAM \& Departamento de Biologia, Universidade de Aveiro, 3810-193 Aveiro, Portugal, ${ }^{4}$ Wildlife Unit, SAC Veterinary Services, Drummondhill, Stratherrick Road, Inverness, IV 2 4JZ, UK, ${ }^{5}$ School of Biological, Earth and Environmental Sciences, University College Cork, BEES, Distillery Fields, North Mall, Cork, Ireland, ${ }^{6} \mathrm{NCB}$ Naturalis, Darwinweg 2, P.O. Box 9517, 2300 RA Leiden, The Netherlands, ${ }^{7}$ ZSL Institute of Zoology, Regent's Park, London, NW1 4 RY, UK, ${ }^{8}$ Instituto Español de Oceanografía, Centro Oceanográfico de Vigo, P.O. Box 1552, Cabo Estay, Canido, 36200 , Vigo, Spain

\begin{abstract}
Peaks in northern bottlenose whale, Hyperoodon ampullatus, strandings are found between August and September in the UK and August and November in The Netherlands, consistent with a hypothesized southward migration. However, results on diet suggest that several whales stranded during these months were not travelling from northern latitudes prior to stranding. We analysed the stomach contents of ten whales stranded in the north-east Atlantic (Scotland, $N=6$, England, $N=1$, Ireland, $N=2$ and The Netherlands, $N=1$ ). All but one of the analysed whales (live-stranded in the River Thames in January 2006) stranded between August and October. Food remains consisted almost entirely of cephalopod mandibles. Twenty-one cephalopod species (16 families) were recorded, the most abundant taxa being Gonatus spp., Teuthowenia spp. and Taonius pavo. No fish and few crustacean remains were found. Small amounts of cephalopod flesh were found in three of the stomachs and none in the others. Given that cephalopod beaks can remain within the stomach for several days, and that there was no evidence of inshore feeding (no coastal species were present among the prey), the whales may not have fed for several days prior to stranding. Three whales had remains of warm-temperate water cephalopods (e.g. Vampyroteuthis infernalis, Heteroteuthis sp.) in their stomachs, while three individuals showed a high diversity of prey in their stomachs, suggesting that several of the whales could have been either travelling north or consistently feeding in temperate latitudes prior to stranding. As previously recorded in other deep diving teuthophagous cetaceans, two animals had ingested small amounts of plastic debris.
\end{abstract}

Keywords: strandings, northern bottlenose whales, Hyperoodon ampullatus, north-east Atlantic, seasonality, diet

Submitted 27 February 2013; accepted 3 December 2013

\section{INTRODUCTION}

The northern bottlenose whale (Hyperoodon ampullatus, Foster, 1770) is a 7-9 $\mathrm{m}$ long beaked whale found only in the northern parts of the North Atlantic Ocean. Its distribution extends from Canadian waters in the west to Norwegian waters in the east, particularly in areas of deep water $(800-1800 \mathrm{~m})$, often along the continental slope (Benjaminsen \& Christensen, 1979; MacLeod et al., 2005; Whitehead \& Hooker, 2012). There is a history of whaling targeting this species (see Reeves et al., 1993 for a review) and although its commercial exploitation stopped in 1977 (IWC, 1978), it was occasionally being hunted in the Faeroe Islands at least until 1993 (Bloch et al., 1996). Most subpopulations of the species are probably still depleted, due to

Corresponding author:

R. Fernández

Email: ruth@mayaproject.org large kills in the past (Taylor et al., 2008). Despite it having being industrially exploited, our knowledge about the biology of northern bottlenose whales is still limited. Indeed, beaked whales (family Ziphiidae) are the least-known group of large mammalian species, which is mainly due to their offshore distribution and long dive duration (Hooker et al., 2002).

Studies addressing diverse aspects of northern bottlenose whale ecology (i.e. distribution, behaviour, diving patterns, genetics, feeding ecology) have been conducted in the Gully submarine canyon (off Nova Scotia, Canada), a region of high density and a potential foraging ground for the species (Gowans et al., 2000; Hooker et al., 2002). Previous studies in the north-east Atlantic have provided some information on diet (e.g. Clarke \& Kristensen, 1980; Lick \& Piatkowski, 1998; Santos et al., 2001), stranding patterns (MacLeod et al., 2004; Rogan \& Hernández-Milián, 2011) and habitat preferences (e.g. Weir et al., 2001). Previous stomach content analyses resulted in the classification of northern bottlenose whales as teuthophagous suction feeders, their feeding mechanism potentially limiting the size of the prey 
that can be consumed (Whitehead et al., 2003; MacLeod et al., 2006). Fish remains were also reported in the stomachs of northern bottlenose whales, both from stranded animals and those hunted commercially. However, in the north-east Atlantic, fish numbers in stomach contents have always been low when compared to cephalopod prey remains (Benjaminsen \& Christensen, 1979; Santos et al., 2001) Whitehead et al. (2003) reported that the northern bottlenose whale shows a very low niche breadth when compared to other teuthivorous mesopelagic marine mammals such as the sperm whale (Physeter macrocephalus, Linnaeus, 1758), Cuvier's beaked whale (Ziphius cavirostris, Cuvier, 1823) and southern elephant seal (Mirounga leonina, Linnaeus, 1758), which was related to the high numbers of the prey species Gonatus spp. present in the samples.

In the north-east Atlantic, northern bottlenose whales are believed to travel towards the northern limits of their distribution range in the spring and return to their southern limits in the late summer, where they spend the autumn and winter (Øien \& Hartvedt, 2011). Peaks in northern bottlenose whale strandings are found in the area during what is thought to be its southern movement between August and October (i.e. Bloch et al., 1996; MacLeod et al., 2004; Rogan \& Hernández-Milián, 2011). However, this may not be the case for all northern bottlenose whales as, for example, small numbers of whales have been sighted year-round in offshore waters of the Norwegian Sea (Øien \& Hartvedt, 2011) and during the summer in the Azores, the southern limit of their distribution range (Silva et al., 2003). These distribution patterns have been also hypothesised to represent a seasonal inshore-offshore movement following prey resources, rather than a north - south migration (Whitehead \& Hooker, 2012).

Besides information on diet preferences, studies of marine top predator feeding ecology (especially those directed to deep diving cetaceans) can also provide insights into poorly-known faunal communities inhabiting oceanic deep waters. Therefore, it is useful to regularly update the available information with results of new analyses of stomach contents in order to provide a longer time series that may track potential changes in prey species availability.

In the present study, stomach contents from ten stranded northern bottlenose whales were analysed to provide new insights into its feeding preferences in the north-east Atlantic, including identification of prey species present, inferences about feeding areas and potential movement patterns, determination of relationships between diet and whale size, comparison of diets of males and females, and comparison of the amount of food in stomachs with estimated daily energy needs. We also summarize the information on the seasonality of strandings of this species in the United Kingdom (1989-2011) and The Netherlands (1584-1993).

\section{MATERIALS AND METHODS}

\section{Strandings monitoring and sample collection}

The stomach contents of ten northern bottlenose whales found along the coast of the UK, Ireland and The Netherlands between 1946 and 2009 were analysed (Table 1). One animal was sighted in the river Thames (UK) in January 2006 and was monitored by veterinary staff from the Institute of Zoology (Zoology Society of London). The attempts to rescue the whale were unsuccessful and the animal was finally euthanased. A full necropsy was performed by members of the Institute of Zoology.

All other stomach contents were collected by regional strandings monitoring networks. Strandings in Scotland were attended by the Scottish Agricultural College Veterinary Services, which also carried out full necropsies. Specimens stranded in Ireland were sampled by the School of Biological, Earth and Environmental Sciences (University College Cork). The stomach contents of the animal stranded in the Netherlands was collected by Naturalis, Nederlands Centrum voor Biodiversiteit. From this latter individual, only a partial sample of the stomach contents was available.

All animals were measured (body length) and sexed, and cause of death was determined when possible. Prey remains consisted principally of cephalopod mandibles (beaks). A crustacean skeleton was also found but species identification was not possible due to being heavily decomposed. Stomach contents were preserved in $70 \%$ ethanol. Stranding locations are shown in Figure 1.

In addition, information on northern bottlenose whale strandings in the UK (1989-2011) and The Netherlands (1584-1993) was assembled to examine the frequency and seasonal distribution of strandings in this species. The majority of the whales included in the present dietary study $(\mathrm{N}=7)$ come from the UK, and a detailed description of the decomposition state of the whales stranded in the area between 1989 and 2010 was available (see Table $S_{1}$ ).

Table 1. Data on stranded Hyperoodon ampullatus (HA) included in the analysis. Reconstructed prey weight for each whale is given. ${ }^{*}$ Denotes a stomach content that was only partially analysed. ${ }^{* *}$ Two individuals stranded together (mass stranding).

\begin{tabular}{lllclll}
\hline Code & Sex & Length $(\mathbf{c m})$ & Weight $(\mathbf{k g})$ & Date & Country & Location \\
\hline HA221 & Male & 750 & - & 5 October 1946 & The Netherlands & Ameland \\
HA602 & Female & 580 & - & 4 September 2001 & Scotland & Scallastle Bay, Isle of Mull \\
HA603 & Female & 615 & - & 31 August 99 & Ireland & Beartragh Island, Killala \\
HA610 & Male & 628 & - & 9 October 2005 & Ireland & Rirgaskiddy, Cork \\
HA210106 & Female & 585 & 1832 & 20 January 2006 & England & London \\
HA19007 & Male & 794 & 7340 & 25 September 2007 & Scotland & Garynahine Lewis, Western Islands \\
HA21208 & Female & 605 & 4760 & 18 October 2008 & Scotland & Loch Eil, Highand \\
HA10309** & Male & 615 & 3400 & 2 August 2009 & Scotland & Cromarty, Highland \\
HA12709 & Male & 599 & - & 24 August 2009 & Scotland & Wigtown Bay, Dumfries and Galloway \\
HA14509 & Male & 584 & - & 8 October 2009 & Scotland & Fort William, Highland \\
\hline
\end{tabular}




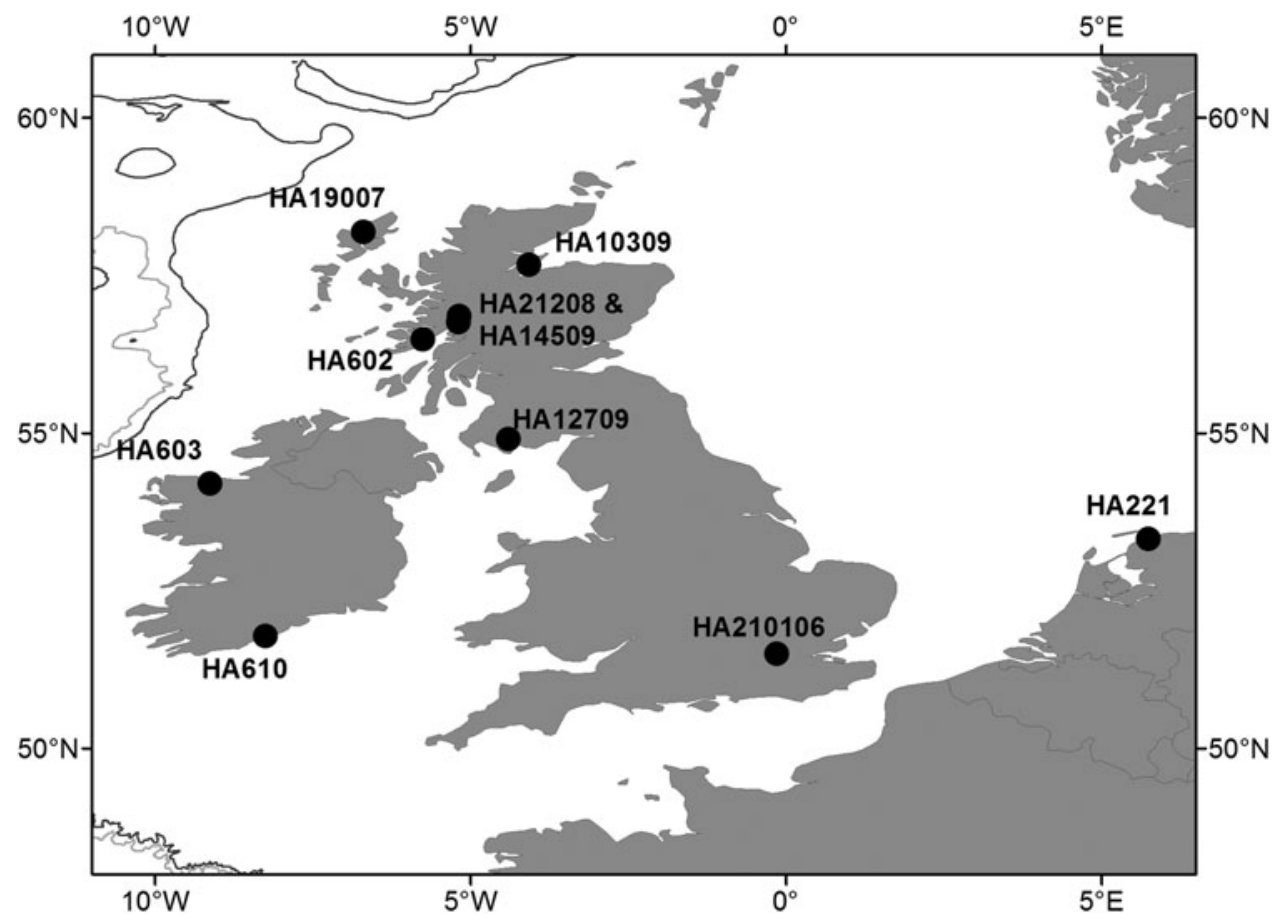

Fig. 1. Stranding locations of the ten northern bottlenose whales included in the present study. Contour lines represent the $-2000 \mathrm{~m}$ (light grey) and $-1000 \mathrm{~m}$ (dark grey) contours.

\section{Sample analysis}

Cephalopod beaks were identified using reference collections held at University of Aberdeen and published guides (e.g. Clarke, 1986). The numbers of cephalopods were estimated from the numbers of upper or lower beaks, whichever was higher. Cephalopod length and weight were calculated from standard measurements on lower beaks (rostral length is the usual measurement for squid beaks, Clarke, 1986) based on a compilation of published regressions (e.g. Clarke, 1986; Santos et al., 2002). For stomachs in which one cephalopod species/size class was represented by $>100$ beaks, a random sample of more than 100 beaks was measured. No published length-weight regressions were available for the taxa Vitreledonella sp. and Cirroteuthidae.

For each prey category, its relative importance in the diet was estimated using two standard indices: (a) contribution by number to the total number of prey; and (b) contribution by weight to the total prey weight.

\section{Statistical analysis}

A Spearman's rank correlation was used to assess correlations between whale and prey sizes. Prey-size/predator-size ratios were calculated by dividing the estimated length of each prey item by the total body length of the cetacean from which it was recovered, following MacLeod et al. (2006). This allowed us to remove the effect of differences in body size between sexes and thus to compare prey sizes in males and females.

Mann-Whitney tests were carried out to determine possible differences in: (1) whale size in relation to whale sex; (2) prey size in relation to whale sex; and (3) prey-size/ predator-size ratios in relation to whale sex.

\section{RESULTS}

A total of 10,665 cetacean strandings was recorded in the UK between 1989 and 2011. From these, 39 correspond to northern bottlenose whales ( $0.37 \%$ of the total) and were distributed from January to December, with highest frequencies in August and September (Figure 2). Slightly more than half (14 out of 22) of the strandings of northern bottlenose whales registered in the UK between August and October corresponded to whales that stranded alive or were freshly dead. From those recorded between November and July, eight corresponded to individuals that were in a moderate to advanced

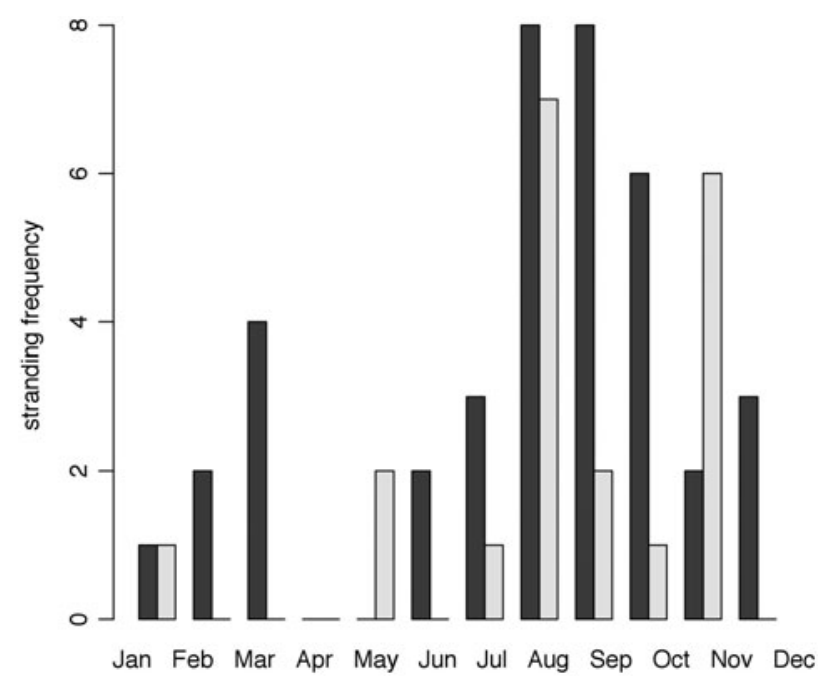

Fig. 2. Seasonal distribution of Brittish (1989-2011; dark grey) and Dutch (1584-1993; light grey) northern bottlenose whale strandings. For one Dutch whale, no data on month of stranding was available (see Table $\mathrm{S}_{1}$ ) and it has not been incorporated in this figure. 
Table 2. Prey species and number of plastic items found in the stomachs of northern bottlenose whales (HA). Numbers of beaks/other remains are indicated (lower beaks, Lb; upper beaks, Ub,). Overall prey species importance $(\% \mathrm{~N}$, percentage by number; \%W, percentage by weight) based on those lower beaks that were taxonomically identified is indicated. No published length - weight regressions were available for Vitreledonella sp. and Cirroteuthidae. The category Histioteuthis type A includes the species H arcturi Robson, 1948, H. corona Voss \& Voss, 1962, H. meleagroteuthis Chun, 1910 and H. bonellii Clarke, 1980. The category Chirotheuthis type II includes beaks of the genus Chiroteuthis different from C. veranyi Ferussac, 1835 (Santos et al., 2001).

\begin{tabular}{|c|c|c|c|c|c|c|c|c|c|c|c|c|c|}
\hline \multicolumn{2}{|l|}{ CEPHALOPODS } & \multicolumn{2}{|l|}{ Ireland } & \multicolumn{5}{|c|}{ West Scotland } & \multirow{2}{*}{$\begin{array}{l}\text { East Scotland } \\
\text { HA } 10309\end{array}$} & \multirow{2}{*}{$\begin{array}{l}\text { England } \\
\text { HA } 210106\end{array}$} & \multirow{2}{*}{$\begin{array}{l}\text { Holland } \\
\text { HA } 221\end{array}$} & \multirow[b]{2}{*}{$\% \mathrm{~N}$} & \multirow[b]{2}{*}{$\% \mathrm{~W}$} \\
\hline Family & Species & HA 603 & HA 610 & HA 19007 & HA 602 & HA 12709 & HA 14509 & HA 21208 & & & & & \\
\hline Octopoteuthidae & Octopoteuthissp. & 2 & - & 1 & - & - & - & - & - & - & - & $<0.1$ & 0.2 \\
\hline Alloposidae & Haliphron atlanticus & - & - & 1 & 16 & - & - & - & - & - & - & 0.3 & 1.3 \\
\hline Galiteuthidae & Galiteuthis sp. & - & - & 2 & 4 & - & - & - & - & - & - & 0.1 & $<0.1$ \\
\hline \multirow[t]{4}{*}{ Histioteuthidae } & Histioteuthis reversa & 20 & - & 7 & 50 & - & - & - & - & - & - & 1.2 & 0.7 \\
\hline & H. melagroteuthis & 1 & - & - & 2 & - & - & - & - & - & - & $<0.01$ & 0.1 \\
\hline & $H$ bonellii & 3 & - & 16 & 6 & - & - & - & - & - & - & 0.4 & 2.4 \\
\hline & H. type A & - & - & 46 & - & - & - & - & - & - & - & 0.7 & 2.7 \\
\hline Lepidoteuthidae & Lepidoteuthis sp. & - & - & 1 & - & - & - & - & - & - & - & $<0.1$ & 0.4 \\
\hline \multirow[t]{2}{*}{ Chiroteuthidae } & Chiroteuthis veranyi & 1 & - & - & 6 & - & - & - & - & - & - & 0.1 & $<0.1$ \\
\hline & C. sp. (type II) & - & - & 2 & 1 & - & - & - & - & - & - & $<0.1$ & $<0.1$ \\
\hline Mastigoteuthidae & Mastigoteuthis schmidti & 1 & - & - & 4 & - & - & - & - & - & - & 0.1 & 0.1 \\
\hline Vampyroteuthidae & Vampiroteuthis infernalis & 2 & - & - & 1 & - & - & - & - & - & - & $<0.1$ & 0.1 \\
\hline Brachioteuthidae & Brachioteuthis sp. & 1 & - & - & - & - & - & - & - & - & - & $<0.1$ & $<0.1$ \\
\hline \multirow[t]{3}{*}{ Cranchiidae } & Teuthowenia megalops & 181 & - & 63 & 1219 & 1 & - & - & - & - & 3 & 25.3 & 8.2 \\
\hline & Teuthowenia type II & 321 & 2 & 61 & 135 & - & - & - & - & 4 & - & 6.0 & 11.8 \\
\hline & Taonius pavo & 928 & - & 136 & 990 & 3 & - & 9 & - & - & - & 32.5 & 18.6 \\
\hline Gonatidae & Gonatus sp. & 142 & - & 199 & 252 & 103 & 28 & 2 & 649 & 493 & 81 & 30.7 & 53.4 \\
\hline Vitreledonellidae & Vitreledonella sp. & 1 & - & - & 31 & - & - & 1 & - & - & - & 0.5 & - \\
\hline Chtenopterygidae & Chtenopteryx sp. & 3 & - & - & 5 & - & - & - & - & - & - & 0.1 & $<0.1$ \\
\hline Sepiolidae & Heteroteuthis sp. & - & - & - & - & - & - & 1 & - & - & - & $<0.1$ & $<0.1$ \\
\hline Cirroteuthidae & - & 1 & - & - & 1 & - & - & - & - & - & - & $<0.1$ & - \\
\hline Octopod (Ub) & & - & - & - & - & 5 & - & - & - & - & - & $<0.1$ & - \\
\hline Broken Lb & & 22 & - & 5 & 68 & 1 & - & - & 2 & 7 & - & 1.7 & - \\
\hline Upperbeaks & & 2649 & - & 1002 & 4212 & 187 & 18 & 71 & 977 & 449 & 150 & & \\
\hline TOTAL & & 2649 & 2 & 1002 & 4212 & 187 & 28 & 71 & 977 & 504 & 150 & & \\
\hline CRUSTACEANS & & - & - & - & - & - & - & - & - & 3 & - & & \\
\hline Plastics & & - & - & 1 & - & - & - & - & - & 2 & - & & \\
\hline
\end{tabular}


decomposition state, four had stranded alive or were freshly dead while the preservation state of five animals was undetermined (Table $S_{1}$ ). Twenty-one northern bottlenose whale strandings were registered in the Netherlands between 1584 and 1993. Most of the strandings took place between May and November, with the exception of one individual that stranded in January and one whale for which the stranding month was unknown. Peaks in frequency of strandings were recorded in August and November (Figure 2).

Numbers of prey items recorded in each stomach ranged between 2 and 4212 (Table 2). Prey remains consisted almost exclusively of cephalopod beaks and belonged to at least 21 different species (16 families), the most abundant taxa being Gonatus spp., Teuthowenia spp. and Taonius pavo (Lesueur, 1821), which together represented more than $90 \%$ of the total diet both by weight and number (Table 2). Gonatus spp. was the most important prey category by weight $(53.4 \%)$, although Taonius pavo (present in high numbers in three of the whales) was the most important category in terms of prey numbers, contributing about $33 \%$ of the total diet (Table 2). A single crustacean exoskeleton was found in the whale stranded in the River Thames (HA210106). Among the whales, we can distinguish two dietary groupings: those dominated by species of the family Cranchiidae (HA602, HA603, HA19007; Table 2) and those dominated by Gonatus spp. (HA221, HA210106, H10309, HA12709, HA14509; Table 2). However, whales HA21208 and HA610 do not perfectly fit either pattern. The stomach contents of the former include more Cranchiidae than Gonatus spp. beaks but not a remarkable diversity of prey species, while the stomach contents of the latter consist exclusively on two beaks of Teuthowenia type II. We should highlight that while whales stranded in Ireland and the West of Scotland contained proportionally more $T$. pavo remains, the three whales stranded in the North Sea contained more Gonatus spp. beaks.
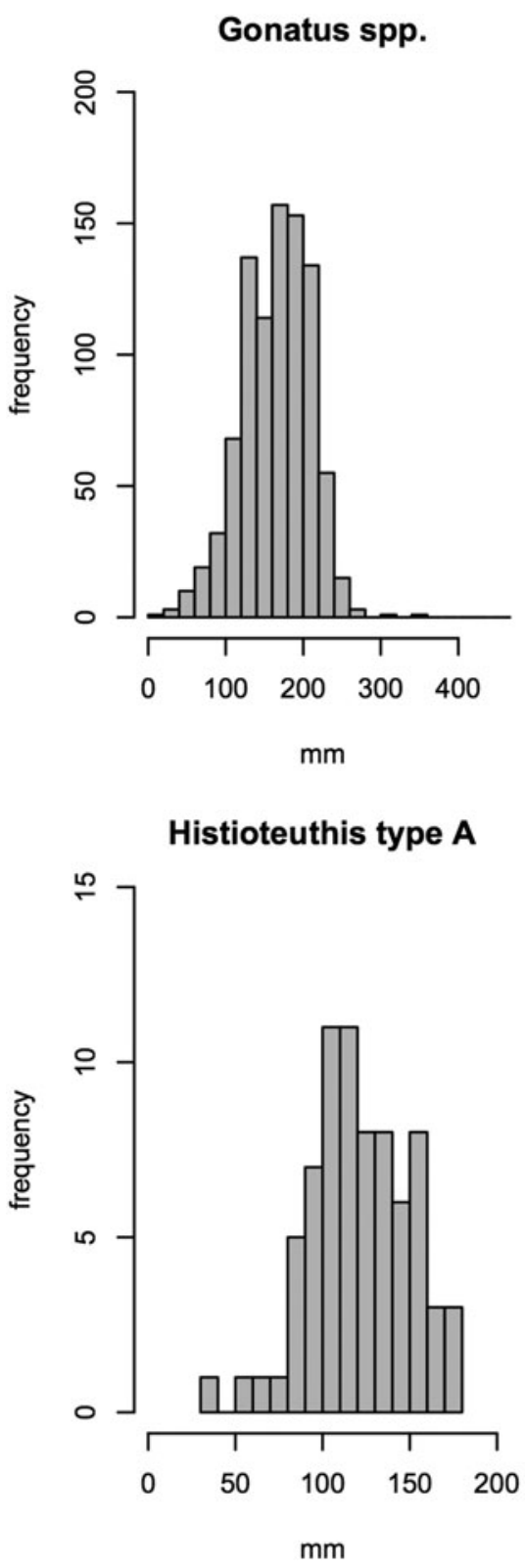

Taonius pavo

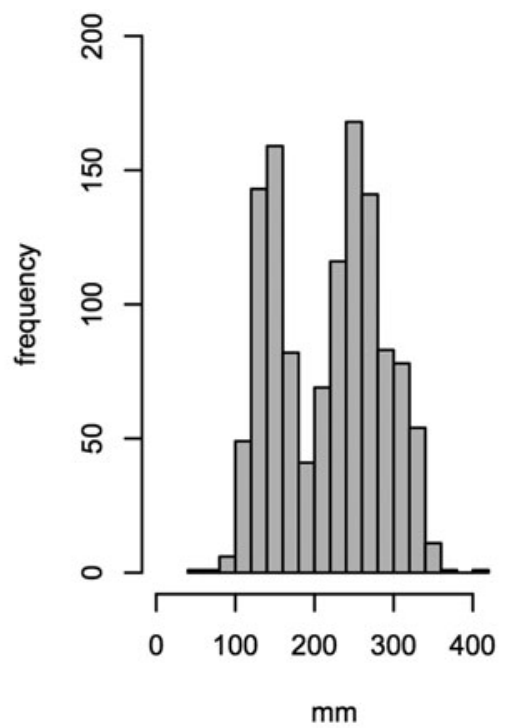

Histioteuthis reversa

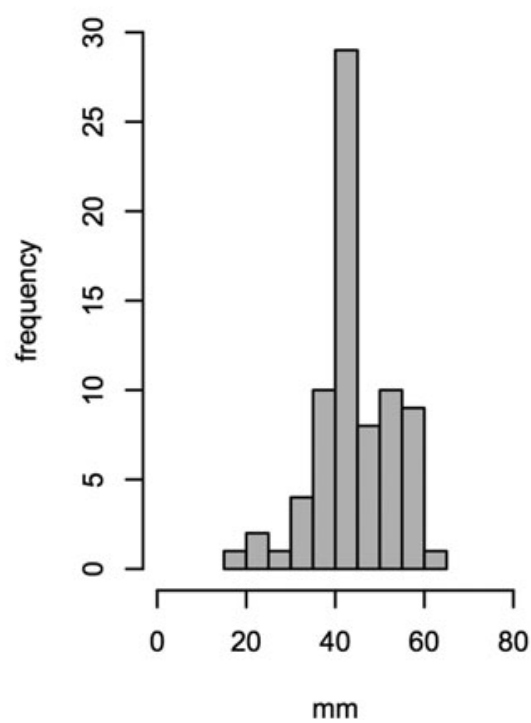

Fig. 3. Frequency distribution of estimated prey size (DML, dorsal mantle length) of the main prey taken by northern bottlenose whales. 
Small pieces of plastic debris were found in two stomachs (HA19007 and HA210106; Table 2), although in small quantities unlikely to have represented a threat to the whales. The whale HA19007 contained an oval-shaped lid of plastic of about $13 \times 8.5 \mathrm{~cm}$. The stomach of the whale stranded in the river Thames (HA210106) contained two small pieces of plastic (of approximately $3 \times 1 \mathrm{~cm}$ and $2 \times 1.5 \mathrm{~cm}$ ) and several other remains probably indicative of its presence and live stranding in the Thames, including a whole potato (Solanum tuberosum, Linnaeus, 1753), green algae and mollusc shell remains.

The main prey categories correspond to oceanic cephalopod species distributed in temperate to sub-polar regions. However, a few beaks of squid characteristic of tropical and warm temperate oceans were also identified (e.g. Vampyroteuthis infernalis, Chun 1903, Heteroteuthis sp.) in whales HA6o2, HA603 and HA21208 (Table 2), which would suggest that at least some of the whales were travelling north prior to stranding. No evidence of inshore feeding was found.

Estimated sizes (dorsal mantle length; DML) of Taonius pavo ranged from 52 to $418 \mathrm{~mm}$, as compared to 18 $341 \mathrm{~mm}$ for Gonatus spp., 48-352 mm for Teuthowenia spp. 39-172 mm for Histiotheuthis type A (this category includes $H$. arcturi, Robson, 1948, H. corona, Voss \& Voss, 1962, $H$. meleagroteuthis, Chun, 1910 and $H$. bonellii, Clarke, 1980), and $19-61 \mathrm{~mm}$ for $H$. reversa, Verrill, 1880 (Figure 3 ). Length-frequency distributions are unimodal for Gonatus spp. (180 mm mode), Teuthowenia spp. (100 mm mode), $H$. reversa $(40 \mathrm{~mm})$ and $H$. type $\mathrm{A}(110 \mathrm{~mm})$, while they are bimodal for Taonius pavo (modes at 150 and $250 \mathrm{~mm}$ ).

Reconstructed squid weights give minimum figures of estimated food eaten by each whale of between $0.1 \mathrm{~kg}$ (for the stomach with just two squid beaks; HA610) to $115.7 \mathrm{~kg}$ (Table 1). Estimates of body weights were available for four individual whales, and in only one case (whale HA210106, weight $c a 1,832 \mathrm{~kg}$, prey weight $\sim 92 \mathrm{~kg}$ ) would the amount of prey represented by the stomach contents have met the whale's daily energy requirements $(\sim 4 \%$ body weight; Sergeant, 1969).

There was a significant positive correlation between whale and prey sizes (Spearman's rank correlation; $P<0.001$ ). Males were not significantly larger than females (MannWhitney test; $P=0.199$ ). For the main prey species (Figure 3), males had eaten significantly larger Taonius pavo $(P<0.001), H$. reversa $(P<0.003)$ and $H$. type A $(P<$ o.030) than females, while females had eaten significantly larger Teuthowenia spp. $(P<0.001)$ and Gonatus spp. $(P<$ o.001) than males. However, when comparing prey-size/ predator-size ratios (obtained by dividing prey size by predator size; MacLeod et al., 2006), only the comparisons involving Taonius pavo and Gonatus spp. remained significant $(P<$ 0.001 in both cases).

\section{DISCUSSIDN}

Two main feeding patterns were found in the whales analysed in the present study; those in which stomach contents were dominated by Gonatus spp. (HA221, HA210106, H10309, HA12709, HA14509) and those dominated by species of the family Cranchiidae (HA602, HA603, HA19007). Whale HA21208 had relatively few beaks in the stomach, but is more similar to the second group as Cranchiidae were most frequent. Whale HA610 was excluded from this classification since only two cephalopod beaks were recovered from its stomach content. The whales with prey items dominated by Gonatus spp., including the three whales stranded in the North Sea basin, were probably travelling south after feeding in higher latitudes, as suggested in previous studies (e.g. Lick \& Piatkowski, 1998; Santos et al., 2001) and consistent with the known distribution of Gonatus fabricii (Kristensen, 1983). On the other hand, the higher diversity of prey present in those stomachs dominated by species of the family Cranchiidae suggests that these individuals could have been feeding further south, in an environment characterized by higher cephalopod diversity (e.g. Spitz et al., 2011), hence probably travelling north prior to stranding. Indeed, two of the latter whales, plus whale HA21208, had remains of cephalopods of tropical and warm temperate oceans (i.e. Vampyroteuthis infernalis, Heteroteuthis sp.) in their stomachs. It is possible that the Gonatus spp. remains found in the whales whose stomachs contents were dominated by Chranchiidae belong to Gonatus steenstrupi (Kristensen, 1981). This latter species has been identified as the main prey category for northern bottlenose whales off the Scotian Shelf (Hooker et al., 2001). Although G. steenstrupi is generally present at lower latitudes than G. fabricii (Lichtenstein, 1818), there is also some overlap in their distribution ranges (see Hastie et al., 2009).

Our results show beaked whale strandings in almost all months of the year with higher numbers in August and November for the Dutch strandings and August and September in UK (Figure 2), fitting the general pattern already reported in the literature (Smeenk et al., 1994; MacLeod et al., 2004) of late summer and autumn stranding peaks around the North Sea. In addition, the majority of the animals examined in the present study that stranded in late summer-autumn were alive or freshly dead, whereas most of those recorded between November and July, and for which preservation state was known, correspond to individuals that were in a moderate to advanced decomposition state. Indeed, most of the stomach contents from northern bottlenose whales analysed to date correspond to individuals stranded between August and October (i.e. Clarke \& Kristensen, 1980; Lick \& Piatkowski, 1998; Hooker et al., 2001; Santos et al., 2001; Spitz et al., 2011). It may be that the poor preservation state of whales stranded outside the peak season, as is the case for Scottish strandings, has resulted in an under-representation of those animals in studies in the north-east Atlantic. Significant seasonal patterns in strandings of Hyperoodon ampullatus were also found by MacLeod et al. (2004) in their analysis of beaked whales strandings around the UK and Ireland from 1800 to 2002 . The authors accounted for differences in effort (e.g. winter-summer) by looking at strandings of individual species relative to all beaked whale strandings, and suggested that this variation could be a reflection of north-south migrations and/or inshore-offshore movements of northern bottlenose whales in the region.

With the exception of the whale examined by Spitz et al. (2011), the stomach contents analyses of northern bottlenose whales in Europe recorded in the literature correspond to strandings at high latitudes (above $50^{\circ} \mathrm{N}$ ). Studies of whales stranded at high latitudes and during what is believed to be the south migration period (August-October) agree on the dominance of Gonatus fabricii as the principal prey species. 
However, different patterns can be found for whales stranded at lower latitudes and outside the peak season: Spitz et al. (2011) found no Gonatus spp. remains in the stomach of an animal stranded in the Bay of Biscay. On the other hand, Santos et al. (2001) found a high diversity of prey in a male stranded in Denmark in February 1997, in which the contribution by number of squid of the family Cranchiidae was higher than that of the family Gonatidae.

Given that Gonatus spp. was not the dominant prey for all of the whales included in this study, three of the whales showed a high diversity of prey species (HA603, HA19007, HA602) and three whales had remains of warm-temperate water cephalopods among their prey (HA603, HA602, HA21208), we suggest that, despite being stranded during the hypothesized period of peak south migration, four of the animals (HA603, HA19007, HA602, HA21208) had been feeding in temperate latitudes prior to stranding.

Prey remains in the partial stomach sample from the whale stranded in the Netherlands in August 1946 were dominated by Gonatus spp. with a small number of Teuthowenia megalops (family Cranchiidae), which is in agreement with findings from other northern bottlenose whale strandings at similar times of the year and geographical area (Lick \& Piatkowski, 1998; Santos et al., 2001).

Considerably higher numbers of upper beaks than lower beaks were recorded in the present study, which indicates an accumulation of upper mandibles. This is a consequence of their shape, which facilitates the accumulation of upper beaks due to several beaks being nested inside each other, and this does not happen for lower beaks (Lick \& Piatkowski, 1998).

No commercially important cephalopod species were recorded in the present study. However, as noted by Hastie et al. (2009), given the high numbers of Gonatus fabricii in the north-east Atlantic, this species may be marketable in the future and it has attracted interest as a potential commercial resource in Norway and Greenland. Gonatus fabricii is an oceanic mesopelagic species of deep offshore waters of the Arctic and North Atlantic, the southern distribution limit of which is around $55^{\circ} \mathrm{N}$ in the north-east Atlantic (Roper et al., 1984). This cephalopod is an abundant food resource exploited by a variety of predators, including whales and seals (Globicephala melaena, Thomas 1898, Physeter macrocephalus, Phoca groenlandica, Erxleben 1777; Potelov et al., 1997; Bjørke, 2001), birds (Fratercula arctica, Linnaeus 1758, Fulmarus glacialis, Linnaeus, 1761; Falk et al., 1992; Garthe et al., 2004), fish (Coryphaenoides armatus, Hector, 1875, Histiobranchus bathybius, Günther, 1877, Seriola dumerili, Risso 1810; Martin \& Christiansen, 1997; Matallanas et al., 1995) and other squid (Illex illecebrosus, Lesueur, 1821; Amaratunga, 1983). Maturation of male Gonatus fabricii occurs at a length of about $200 \mathrm{~mm}$, with maximum lengths being 350 and $380 \mathrm{~mm}$ for males and females, respectively (Hastie et al., 2009). No comparable information is available at present for Gonatus steenstrupi. The whales included in this study had most likely eaten mainly immature squid.

\section{ACKNDWLEDGEMENTS}

Many thanks to Chris Smeenk for suggestions concerning Dutch Hyperoodon strandings. Thanks to Guido Keijl for access to the Dutch stranding database.

\section{FINANCIAL SUPPDRT}

Data and samples from the UK were provided by the UK Cetacean Strandings Investigation Programme, which is jointly funded by Defra (UK Department of Environment Fisheries and Rural Affairs) and the Devolved Administrations in Scotland and Wales. R.F. was supported during part of the research period through an AXA Postdoctoral Research Grant (grant number 32983). GJP acknowledges financial support from Caixa Geral de Depósitos (Portugal).

\section{Supplementary materials and methods}

The supplementary material referred to in this article can be found online at journals.cambridge.org/mbi.

\section{REFERENCES}

Amaratunga T. (1983) The role of cephalopods in the marine ecosystem. In Caddy I.F. (ed.) Advances in Assessment of World Cephalopod Resources. FAO Fisheries Technical Papers No. 231, pp. 379-415.

Benjaminsen T. and Christensen I. (1979) The natural history of the bottlenose whale, Hyperoodon ampullatus (Forster). In Winn H.E. and Olla B.L. (eds) Behaviour of marine animals. Volume 3: cetaceans. London: Plenum Press, pp. 143-164.

Bloch D., Desportes G., Zachariassen M. and Christensen I. (1996) The northern bottlenose whale in the Faeroe Islands, 1584-1993. Journal of Zoology 239, 123-140.

Bjørke H. (2001) Predators of the squid Gonatus fabricii (Lichtenstein) in the Norwegian sea. Fisheries Research 52, 113-120.

Clarke M.R. and Kristensen T.K. (1980) Cephalopod beaks from the stomachs of two northern bottlenosed whales (Hyperoodon ampullatus). Journal of the Marine Biological Association of the United Kingdom 60, $151-156$.

Clarke M.R. (1986) A handbook for the identification of cephalopod beaks. Oxford: Clarendon Press.

Falk K., Jensen J.K. and Kampp K. (1992) Winter diet of Atlantic puffins (Fratercula arctica) in the northeast Atlantic. Colonial Waterbirds 15, $230-235$.

Garthe S. Montevecchi W.A. Ojowski U. and Stenhouse I.J. (2004) Diets of northern fulmar (Fulmaris glacialis) chicks in the northwest Atlantic Ocean. Polar Biology 27, 277-280.

Gowans S., Whitehead H., Arch J.K. and Hooler S.K. (2000) Population size and residency patterns of northern bottlenose whales (Hyperoodon ampullatus) using the Gully, Nova Scotia. Journal of Cetacean Research and Management 2, 201-210.

Hastie L.C., Pierce G.J., Wang J., Bruno I., Moreno A., Piatkowski U. and Robin J.P. (2009) Cephalopods in the North-Eastern Atlantic: species, biogeography, ecology, exploitation and conservation. Oceanography and Marine Biology: an Annual Review 47, 111-190.

Hooker S.K., Iverson S.J., Ostrom P. and Smith S.C. (2001) Diet of northen bottlenose whales inferred form fatty-acid and stable-isotope analyses of biopsy samples. Canadian Journal of Zoology 79, 14421454 .

Hooker S.K., Whitehead H., Gowans S., Baird R.W. (2002) Fluctuations in distribution and patterns of individual range use of northern bottlenose whales. Marine Ecology Progress Series 225, 287-297.

IWC (1978) Chairman's Report of the Twenty-ninth Meeting. Reports of the International Whaling Commission No. 28, pp. 18-27. 
Kristensen T.K. (1983) Gonatus fabricii. In Boyle P.R. (ed.) Cephalopods life cycles, Volume 1, Species accounts. London: Academic Press, pp. 159-174.

Lick R. and Piatkowski U. (1998) Stomach contents of a northern bottlenose whale (Hyperoodon ampullatus) stranded at Hiddensee, Baltic Sea. Journal of the Marine Biological Association of the United Kingdom 78, 643-650.

MacLeod C.D., Pierce G.J. and Santos M.B. (2004) Geographic and temporal variations in the strandings of beaked whales (Ziphiidae) on the coasts of the UK and the Republic of Ireland from 1800-2002. Journal of Cetacean Research and Management 6, 79-86.

MacLeod C.D., Perrin W.F., Pitman R., Barlow J., Ballanca L., D'Amico A., Gerrodette T., Joyce G., Mullin K.D., Palkay D.L. and Waring G.T. (2005) Known and inferred distributions of beaked whale species (Cetacea: Ziphiidae). Journal of Cetacean Research and Management 7, 271-286.

MacLeod C.D., Santos M.B., López A., Pierce G.J. (2006) Relative prey size consumption in toothed whales: implications for prey selection and level of specialization. Marine Ecology Progress Series 326, 295307

Martin B. and Christiansen B. (1997) Diets and standing stocks of benthopelagic fishes at two bathymetrically different midoceanic localities in the northeast Atlantic. Deep-Sea Research Part 1 44, 541-558.

Matallanas J., Casadevall M., Carrasson M., Boix J. and Fernandez V. (1995) The food of Seriola dumerili (pisces: Carangidae) in the Catalan sea (western Mediterranean). Journal of the Marine Biological Association of the United Kingdom 75, 257-260.

Øien N. and Hartvedt S. (2011) Northern bottlenose whales Hyperoodon ampullatus in Norwegian and adjacent waters. Cambridge: International Whaling Commission, IWC SC/63/SM1, 8 pp.

Potelov V., Nilssen K.T., Svetochev V. and Haug T. (1997) Feeding habits of harp Phoca groenlandica and hooded seals Cystophora cristata during moult (April to June) in the Greenland sea. North Atlantic Marine Mammal Commission Scientific Publications 2, 40-49.

Reeves R.R., Mitchell E. and Whitehead H. (1993) Status of the northern bottlenose whale, Hyperoodon ampullatus. Canadian Field Naturalist $107,490-508$

Rogan E., Hernández-Milián G. (2011) Preliminary analysis of beaked whale strandings in Ireland: 1800-2009. Cambridge: International Whaling Commission, IWC SC/63/SM19, 16 pp.

Santos M.B., Pierce G.J., Smeenk C., Addink M.J., Kinze C.C., Tougaard S. and Herman J. (2001) Stomach contents of northern bottlenose whales stranded in the North Sea. Journal of the Marine Biological Association of the United Kingdom 81, 143-150.

Santos M.B., Pierce G.J., García Hartmann M., Smeenk C., Addink M.J., Kuiken T., Reid R.J., Patterson I.A.P., Lordan C., Rogan E. and Mente E. (2002) Additional notes on stomach contents of sperm whales Physeter macrocephalus stranded in the NE Atlantic. Journal of the Marine Biological Association of the United Kingdom $82,501-507$.

Sergeant D.E. (1969) Feeding rates of cetacea. Fiskeridirektoratets skrifter (ser. Havundersøkelser) 15, 246-258.

Silva M.A., Prieto R., Magalhães S., Cabecinhas R., Cruz A., Gonçalves J. and Santos R. (2003) Occurrence and distribution of cetaceans in the waters around the Azores (Portugal), summer and autumn 1999-200o. Aquatic Mammals 29, 77-83.

Smeenk C., Addink M. and García Hartmann M. (1994) Vreemde walvissen op onze kusten: deel 2: de butskop. Zoogdier 5, 8-15.

Spitz J. Cherel Y., Bertin S., Kiszka J., Dewez A., Ridoux V. (2011) Prey preferences among the community of deep-diving odontocetes from the Bay of Biscay, Northeast Atlantic. Deep-Sea Research Part 1 58, $273-282$.

Taylor B.L., Baird R., Barlow J., Dawson S.M., Ford J., Mead J.G., Notarbartolo di Sciara G., Wade P. and Pitman R.L. (2008) Hyperoodon ampullatus. In IUCN Red List of Threatened Species. Gland, Switzerland: International Union for Conservation of Nature.

Weir C.R., Pollock C., Cronin C. and Taylor S. (2001) Cetaceans of the Atlantic frontier, north and west of Scotland. Continental Shelf Research 21, 1047-1071.

Whitehead H., MacLeod C.D. and Rodhouse P. (2003) Differences in niche breadth among some teuthivorous mesopelagic marine mammals. Marine Mammal Science 19, 400-106.

and

Whitehead H. and Hooker S. (2012) Uncertain status of the northern bottlenose whale, Hyperoodon ampullatus: population fragmentation, legacy of whaling and current threats. Endangered Species Research $19,47-61$

\section{Correspondence should be addressed to:}

R. Fernández

Centre for GeoGenetics

University of Copenhagen

Øster Volgade 5-7, 1350

Copenhagen, Denmark

email: ruth@mayaproject.org 